\title{
地震災害対策と地震予知とのシステム分析
}

\author{
名古屋大学理学部地球科学教室 島 津 康 男 \\ (昭和 50 年 10 月 25 日受理)
}

\section{Systems Analysis of Earthquake Disater and Earthquake Prediction}

\author{
Yasuo SHIMazu \\ Department of Earth Sciences, Nagoya University
}

(Received October 25, 1975)

\begin{abstract}
Disaster due to earthquake in Japan is characterized by indirect and long-term impacts by collapse in administration, information, and communication systems. Damages and corresponding actions are discussed based on a systems concept. Four types of actions are distinguished as: destruction proof, dispersion, fail safe, and repair. The latter two are espcially important to protect systems function. Earthquake prediction is also discussed in relation to possible actions. The prediction at one year before the zero day is significant with respect to systems protection. Mass evacuation appears to be impossible. An interdisciplinary research of prediction connecting seismology and social-human sciences is proposed.
\end{abstract}

\section{§1. はじめに}

不幸にして地震に抢そわれた場合，怖いのは地震そのものよりも，むしろ火炎による二次災 害であり，車や地下街の混乱であるとは，よく指摘されている，だが，過密な高度工業国であ る日本では，問題はそこに止まらない，日本の地震災害は都市型であるところに特徵がある。 都市型の災害とは

“直接に建物の下敷きになる人や，火災によつて死亡する人に比べ，都市のシステム機能の まひによつて，間接にまた長期的に影響を受ける人の方がずつと多い” ことである。

その中でも，政治・経済・文化の諸活動の異常なまでの集中度のゆえに，東京の地震災害は 日本全体をまひさせる恐れがある，地震災害に対する対策も，間接的だが長期にわたるシステ ム機能の防御に対応したものでなくてはならない。二次災害とは，火災に対していうべき語で はなく，システムまひに与えるべき語である。

昭和 50 年 10 月 5 日発表 


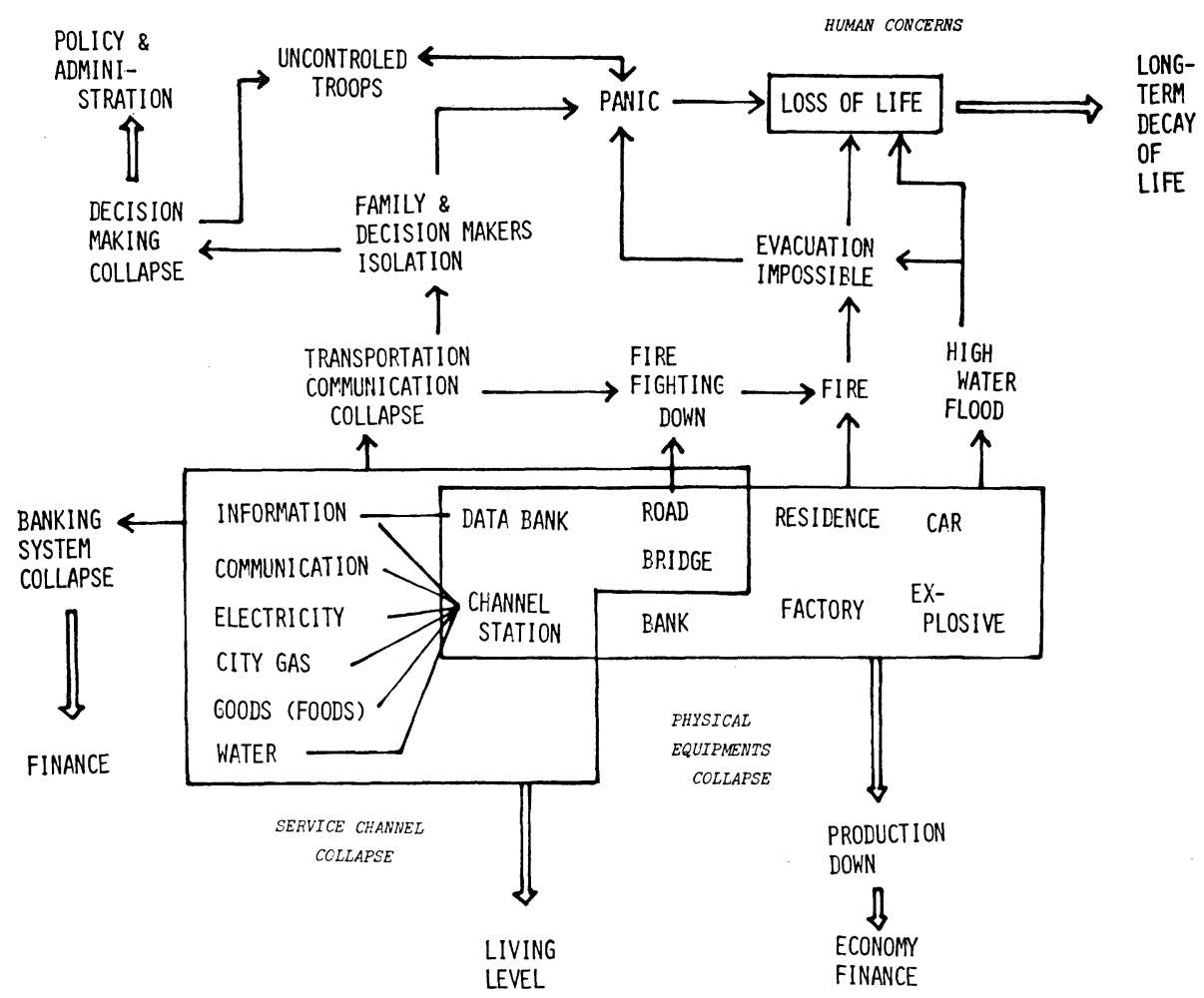

Fig. 1. System structure of earthquake disaster. Three types of elements are distinguished: physical equipment, service channel, and human.

\section{§2. 地震災害の分析}

都市型の地震災害の構造を Fig. 1 (地震発生時) と Fig. 2 (長期的なもの) に示した. 矢 印は因果関係の方向を示し，Fig. 1 の中抜き矢印が Fig. 2 につながつている. 重要な点に説 明を加えよう。

Fig. 1 において，一次的に破壊をたは機能のダウンをらけるものを

物理的な施設（住宅，工場…․)

サービス・チャンネル

の 2 つねけけてある。給水・通信などはシステムの機能を保つためのチャンネルであり, 物理 施設の間をつなぐものである。チャンネルには, 通信線・パイプライン・電力線・道路及び橋 などがあり，それぞれによつて情報・エネルギー・資材・人が運ばれるわけである，個人の生 活はシステムの中にとりこまれており，停電すれば米もたけなくなるとは，よく指摘される。

しかし，これまで余り指摘されていない災害として，次のものがある。

（1）昼間人口と夜間人口 


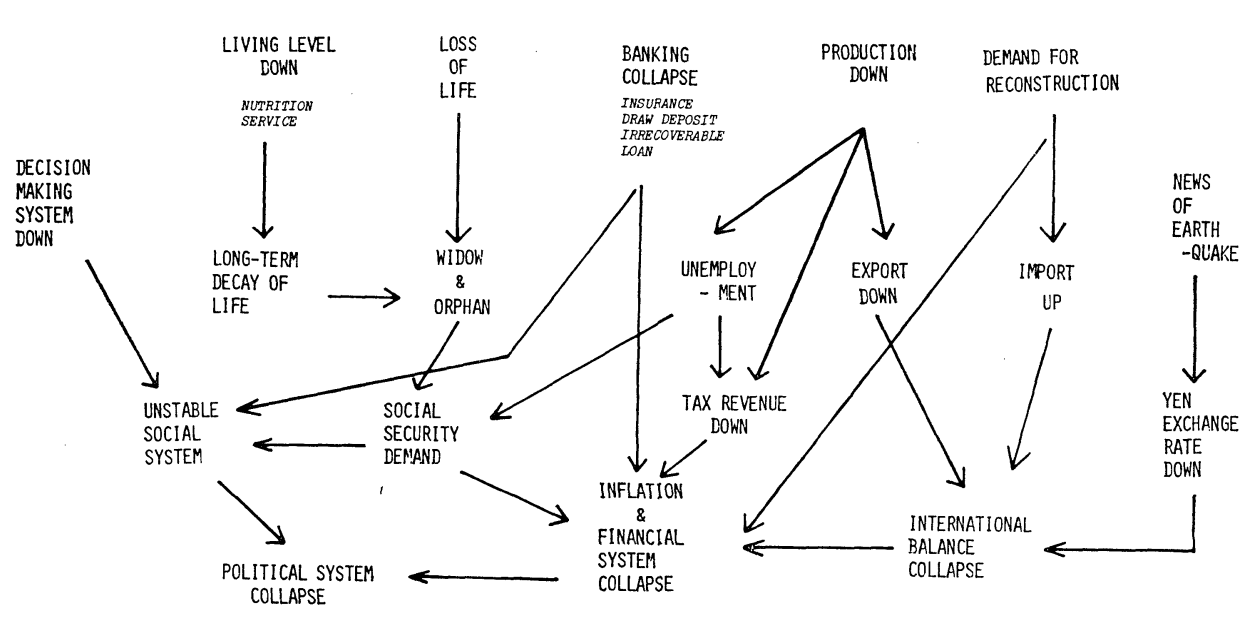

Fig. 2. System structure of indirect and long-term impacts after earthquake.

昼間に地震があると，都心の通勤者と郊外の家族とがひき離されてしまう。電話連絡は絶た れ, 通勤圏が数 $10 \mathrm{~km}$ にもなると, 徒歩帰宅は大変だし, 道路の混雑は緊急処置の支障とな る. 家族離散の状態でコミュニケーションがたたれたら，パニックの危険が大きい.

（2）意思決定システムのまひ

日本の行政組織の特徵として, 意思決定の責任分散がある。つまり個人の権限が小さい，そ こで，意思決定者群の離散によつて，対策の発動がおくれてしまう。ささに，現在の法制では， 緊急時の命令権継承がはつきりしていない，政府首脳の分散，首相と天皇との連絡不能による 国会の開催不能，など，意思決定システムの災害時対策がない，政府首脳・国会議員が全国に 分散している総選挙中に東京に地震があつたら，どうなるだろらか．また，東京の地震災害対 策の責任者が都知事というのもいかがだろらか. 東京の地震は日本の地震なのである.

(3) データバンクの破壊

銀行業務をはじめとして，各企業・官庁の業務はコンピュータ化されている，たと光建物は こわれず，人の損失もなくても，データバンクの破壊によつてシステムがまひする．新幹線を はじめとして交通・輸送システム自身がコンピューターによつて管理されていることも重大で ある。

Fig. 2 の長期災害は，特に東京が地震におそわれた時に重要な意味をもつ. 恐らく，円の 暴落だけで, 日本の経済力は壊隇するのではないか.これは石油ショックの影響より1桁大き いとの予想から推定できる。 


\section{§3. 災害対策の分析}

Fig. 1 にみたように，破壊なたは機能の低下する要素を，物理的施設 $(\mathrm{P})$ ，チャンネル (C)，人 $(\mathrm{H})$ の 3 つと考えることができる. 二次災害，すなわち一つの要素の破壊が他の要 素に波及することまでを考光ると，災害の基本型は P, C, H の組み合わせとして，Fig. 3 の

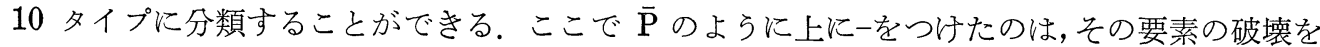
示し，例えば P $\overline{\mathrm{CP}}$ は，物理的施設をつなぐチャンネルの破壊を示している．Fig. 1 は，こ れら基本型災害の集合として理解される。

さて，災害対策とは，Fig. 3 の基本型の各々に対する対策の集合であるが，対策そのもの には，事前対策 (PRIOR) と事後対策 (POST) との 2 つがありうる。 その例は Fig. 3 に示 してある。しかも，その対策の内容は大きくわけて次の 4 つのタイプに分類できるだろう。す なわち

（A）こわれないように強くする（耐震・耐火）

（B） 共倒れしないようにする（分散）

（C）予備またはコピーを作つておく（フェイル・セイフ）

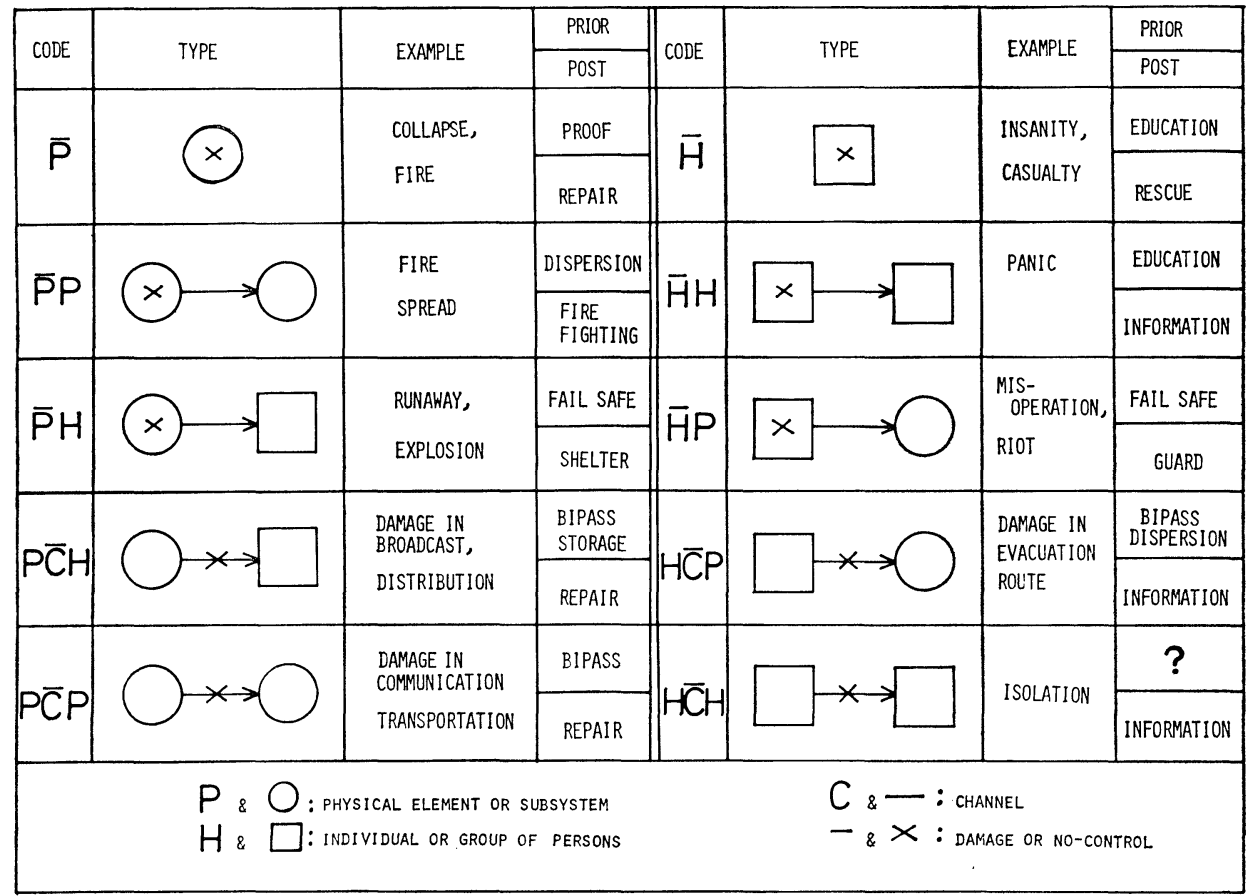

Fig. 3. Classification of fundamental damages and corresponding actions (PRIOR: actions before earthquake, POST: actions after earthquake). 
(D) 壊れた時直しやすいようにしておく（修復重視）

であり，

物理的施設には $(\mathrm{A}) ，(\mathrm{~B})$

チャンネルには (C)，(D)

の対策が向いている，そして当然のことながら，(A)，(B) では対策に時間がかかるから，そ の場になつては間に合わない，(C)，(D) の特徵は，予備やコピーの機能を維持するのに手間 (コスト) がかかるところにあり，従つて直前に手を打つた方が有利である。現在の対策は (A)，(B) に偏よりすぎている.

具体的な対策としては

（1）人命に直結する対策，つまり Fig. 1 で人命損失のボックスに直接矢印が向いている 災害の対策を優先し，(A)〜 (D) を重複しても構わない.

（2）全体への波及の著しい部分，つまり Fig. 1 で矢印が沢山出ているところを優先する.

（3）（A）（D）のぞれがいいかは，対策のためのコストと，それによつて防げる損害額と の比で判断する.

の 3 つの原則に従うものとする.

以上の考察をへて，特に留意すべき対策のいくつかを列挙しょう.

（a）〔情報・コミュニケーションのステーションの分散〕地震による壊滅的㷋 害は半径 $30 \mathrm{~km}$ 止まりだから，放送局をこの程度に分散し，かつサービスェリアが重なるようにする. 同一市内の各局（民放をも含む）はコピー同志と考光，災害時には同じニュースを流す，局に よつて違つたニュースを流すと，疑心暗鬼の原因になり，パニックを拈こしやすい．このこと は，一元化された対策本部及び放送局のチャンネル確保の重要性を意味している．暴動に対す る放送局の防衛体制も重要である.

さらに，個人レベルのコミュニケーション（尋ね人的なもの）にも放送局を利用することを 考える。個人離散に伴なうコミュニケーション断絶の危険は前に強調した。個人サイドでは, トランジスタラジオを用意すること、これに比べると，個人レベルの非常食糧を用意すること は，有効度が知れている。これも分散対策の一例ではあるが，長期間にわたってシステムとし て供給すべき量の方がはるかに大きいからである.

（b）【意思決定システム・データバンクのコピー】この必要性は前述した。長期対策とし ても，実現可能なのはこの程度ではなかろうか. 


\section{§4. 地震予知の分析}

“地震はなぜ扣こるか”がわかることは，学問的にも重大な意味をもつ，しかし，㷋害を少 なくするための予知を標傍するなら，

どのように公表するか

どんな対策をとるべきか

対策のための意意決定にどうつなぐか

を前提にすべきで，これは地震学の枠内には止まらない。観測データの積み上げは必要条件と しても，行政・社会体制との対応を考光ねば十分条件とはいえない，前節の各対策を予知と結 びつけることは, 各対策の時間的順序, つまり予知が可能な場合何を先にすべきかの選択を行 ならことに対応している。

Fig. 4 は，地震予知を発表日と精度との関係で示したものである。横軸には

ゼロデーからの時間，つまり後何日で地震があるか

をとり，縦軸には

不確かさの程度

をとつてある。“1年以内に地震がある”という場合，これは正確には

“今日から 1 年後までの間の何時かにおこる”

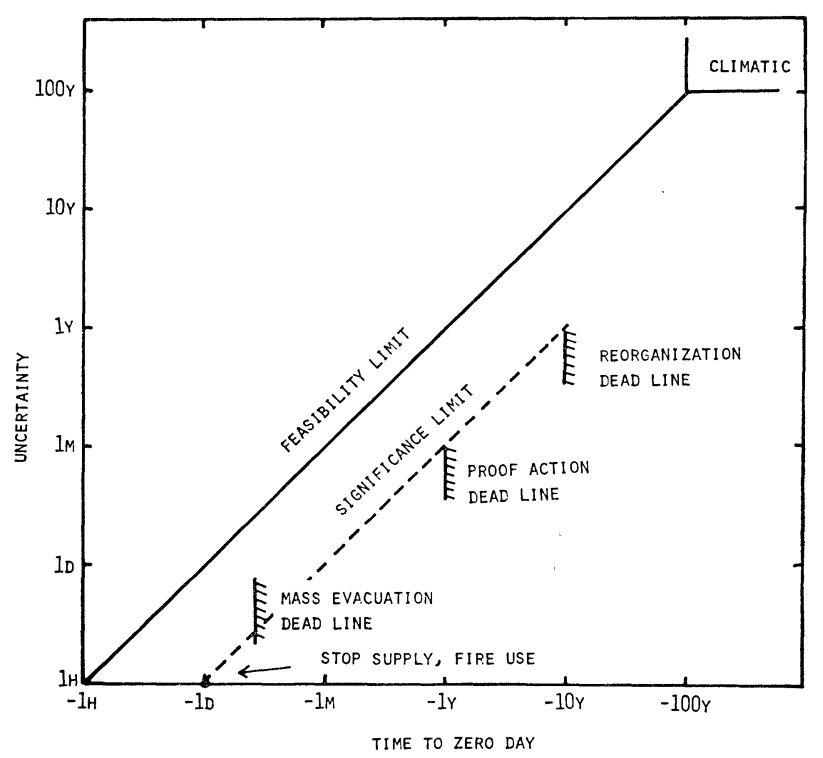

Fig. 4. Date of issue-uncertainty relation in earthquake prediction. Dead lines for various actions are represented by shades. 
といらべきで，発表はゼロデーから「ー1年」，その不確かさは「1年」ということだと，実 は予知として余り役だたない. Fig. 4 で feasibility limit (実行限界) と書いた 45 度の直線 は，「ゼロデーからの日二不確かさ」を示し，不確かさがこれより大さくては，予知の意味は

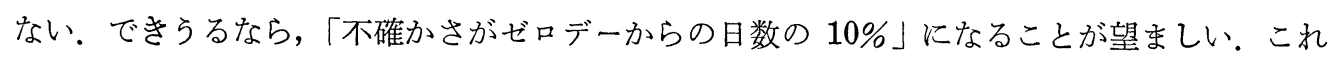
が significance limit (有意限界) であつて, 例えば 1 年後に括こる地震を 1 月ぐらいの精度 で（11 ケ月から 12 ケ月の間に拈こると）予知することを意味する.

さて, ゼロデーまでの日数に応じて, 予知に伴なう対策の内容は当然変つてくる. その代表 的なものをあげよう。

(1) 10 年後に地震がある

耐震・耐火都市，過密地域の整理，防火帯・避難空間の建設など，都市の再編につながる $\S 3$ の対策 (A)，(B) には長年月がかかる，特に今のように，自治体が自分の責任で行なわね ばならず，政府の志向する公共事業が都市より地方を重視しているような情勢では，10 年で はとても無理である。つまり，10 年前に地震のあることがわかつても，時はすでに抢そいの である、だが，このような対策は地震予知がなくても可能で，過去の傾向から，重点対策の必 要な地域は今でもわかつている (Fig. 4 の climatic（気候的）予知).すなわち，今努力され ているような子予知は，これらの対策にとつて特にメリットがあるわけではない。

（2） 1 年後に地震がある

常識的にみて, 地震予知の内容は時とともにはつきりしてくるものであろう.10 年後とい らことがわかつてから，観測をつづけるらちに 1 年後といらことがわかつてくる．また，直下 型の地震なら，一足とびにこの段階からはじまるかもしれない.

ここに至つては, 対策 $(\mathrm{A})$ としては重要な道路・橋・堤防の補強がせいぜいで，チャンネ ル関係の $(\mathrm{B}),(\mathrm{C})$ 対策を重点的に行なう時期である。意思決定者の 継承順位を決めておく こと，データバンクのコピーを東京と大阪に作つておくことなど，システムへの対策の特徵は, 維持のコストが高くつく点にある。1 1 年以上予備システムを保つのはむずかしく，「1年」と いう地震予知は，その点非常に有効である。

（3） 1 月〜 1 週後に地震がある

さらに，ゼロデーの焦点がはつきりしてきて，1月ということになると，とるべき対策は人 命に直接関係したものに移つてくる，考えられるのは，事前の集団避難であるが，これが可能 なための条件として，次のものがあげられる.

輸送順位 (残留要員の確保)

輸送スケジュール（自家用車の禁止含む） 
行く先の食, 住確保

輸送に要する期間が数日以下であること（長びくとパニック）

予知を誤まり，空ぶりに終つても，次の機会にまた市民がいうことを聞く強い統制 が必要で，これらのどれか一つを欠いてもパニックを抗こし，さらに悪い結果になる。 システ ム防御のため，特定の人物たとえば政府首脳だけを避難させるのも，情報がもれた時の反作用 によるパニックがより怖い，徒歩による避難が可能な 10 万都市ならいざ知らず，日本の大都 市では集団避難は無理であろう.

（4）明日地震がある

この時点では, 工場の操業を止め, 電気・ガスを供給側で停止して火災発生を防ぐなどの対 策しかない，水の供給を止めないためには，そのための電力供給を続ける必要があるが，恐ら く水のパイプラインは破壊され, 消火用の水供給はまひするだろう。従つて, 水も備蓄や池・ 川に頼らざるをえまい，この点都市の川を埋め立てているのは，まことに危険である，筆者は， この点を含め水を中心にした都市を提案しているが [島津 (1974), SHIMAZU et al. (1975)] , 対策 (A) の中心におくべきものである。またガソリンスタンドの封印 $\rightarrow$ 自家用車の ガソリン をゼロにしておく，などの処置も 1 週間前から必要であろう。しかし，(1)，(2) の対策がす んでいれば，(3) の集団避難がなくても，(4) によつて災害は相当へらすことができる，もつ とも，震度 VII の地震には，ぞの対策も有効とはいえまい。

現在，地震災害に対する政治家の関心があるとすると，それは

都市改造をする

地震予知を可能にする

の二つである, 前者は $\S 3$ の対策 (A) に相当し，元来地震予知の可能性とは関係ない。つま り，両者は別の問題である。そればかりか，予知によつて，その場しのぎの災害減少が可能に なるなら，時間も金もかかる都市改造をしないでもすむわけで，上記二つを真面目に取り上げ れば，両者は論理的に矛盾してくる。この矛盾をつなぐのが，本節の (2) であろう。つまり， 都市改造をした上で， 1 年前のシステム防御をすることが重要なのである.

同様の意識は一般市民の方にも見られ，改造と予知とが分離したままになつている，前記の (1)～(4) はそのまま市民への啓もう・教育のプロセスをも示している，科学者たる者は，政 治家と市民との両方に啓もう・教育の努力をする責任がある：これらを考えると，観測オンリ 一の地震学研究者のみによる地震予知は片手落であり，これが公表の責任まで負うとすれば危 険でさえある，行政との連結までを考えるのは時期尚早としても，少なくも社会・人間科学を 
含めた地震予知研究体制が必要であろら。それも，心理学といつた個人レベルの反応の研究で なく，人間集団・組織（企業・行政）を含むシステムとしての挙動が含まれねばならない，米 国の予知研究にはこの部分が含まれているが，それも地震保険の可能性などについてはじまつ たばかりと聞く、ボストン (文化)・ニューヨーク (経済)・ワシントン (政治) の機能を一手 に引き受けた形の東京では, 米国とは比べのにならぬ程, 地震予知の波及効果は複雑かつ大 きいのではないか.

以上の議論に数值が入つていないことに，不満を持つ方も多いだろう。首都圈の大地震によ る国家的経済面への波及効果についての数値的推定がなされた例はあり，

被害総額 $\quad 40 \sim 50$ 兆円

所得低下 $17 \sim 19 \%$

物価上昇 3 倍

復興可能率 $30 \%$

となつている [米田 (1975)]。もつとも，これは石油ショック時の経済変動をもとに推定した ものにすぎない，我々としては，災害のシステム構造を求めるのが先決と考えており，これが すめば数量化は不可能ではない。これは今後の，専門家チームによる研究課題である.

な掞，この仕事は日本列島をどのように改造するかの，筆者の「国土科学」の一部をなすも のである，そこでは，エネルギー，食糧，環境などの問題と，災害に対してナショナル・セキ コリテイ・ミニマムを維持することが同列にかつ総合的に扱かわれる，それは，自然科学と社 会人間科学にまたがる意味で本質的に学際的である，(この意味で，同じ自然科学の中で違つ た領域にまたがるのは学際といわない)，学際研究といえば多くの専門家がチームを組むのが 普通だが，我々は少数ではあるが個人個人が学際的な研究者によるチーム研究を行なつている。 地震予知研究も, 初期にはこのような型式で学際を志向するのもよいであろう.

\section{文献}

島津康男, 1974, 国土科学 (NHK ブックス), 日本放送出版協会, 213 .

Shimazu, Y., T. Urabe and K. SugiYama, 1975, Ecological Approach in National PlanningConversion into Nature Oriented Japan. Presented at International Congress of Scientists on the Human Environment, Kyoto, 88.

石原舜介 (編), 1973, 都市社会システム, システム工学講座 10. 4.4 都市災害防止システム, 日刊工 業新聞社, $329-349$.

米田匠滋, 1975, 大地震で発生するカタストロフ的状況，日本が壊隇する日（複合大地震の政治経済的 研究), エコノミスト臨時増刊, 28-37. 